\title{
Fatty Acids and Tocopherols Contents of Cameroon Oil Palm from Three Varieties of Elaeis guinensis jack
}

\author{
Ndomou Mathieu, ", Kotué Taptue Charles², Ngando Ebongue Georges Frank³, \\ Ngogang Yonkeu Jeanne ${ }^{4}$ \\ ${ }^{1}$ Department of Biochemistry, Faculty of Science, University of Douala, Douala, Cameroon \\ ${ }^{2}$ Department of Biochemistry, Faculty of Science, University of Yaounde I, Yaounde, Cameroon \\ ${ }^{3}$ Specialised Center for Research on Palm Oil, Institute of Agricultural Research for Development (IRAD) of Dibamba, Dibamba, Cameroon \\ ${ }^{4}$ Department of Physiological and Biochemical Sciences, Faculty of Medicine and Biomedical Sciences, University of Yaounde I, Yaoundé, \\ Cameroon
}

\section{Email address:}

nmathieu2009@yahoo.fr (N. Mathieu)

\section{To cite this article:}

Ndomou Mathieu, Kotué Taptue Charles, Ngando Ebongue Georges Frank, Ngogang Yonkeu Jeanne. Fatty Acids and Tocopherols Contents of Cameroon Oil Palm from Three Varieties of Elaeis guinensis jack. International Journal of Nutrition and Food Sciences.

Vol. 5, No. 1, 2016, pp. 68-71. doi: 10.11648/j.ijnfs.20160501.20

\begin{abstract}
This study aimed at evaluating fatty acids and tocopherol contents of oil palm extracted from fruits of three varieties of Elaeis guinensis jacq namely Tenera, Dura and Pisifera. Oil was extracted from mesocarp of cooked palm nuts using continuous device of soxhlet. Fatty acids contents were determined by gas chromatography of methyl esters and tocopherols were measured through High Pressure Liquid Chromatography (HPLC). Results showed that unsaturated fatty acids contents was more than $52 \%$ in crude oils from the first cycle palm oil and decrease significantly $(\mathrm{P}<0$, 05) in Dura second cycle oil. Changes occurred in fatty acids profile of Tenera and Dura. Ratio of polyunsaturated fatty acids over saturated fatty acids was higher in Pisifera (0.40). Total tocopherol contents of palm oil were more than $738 \mathrm{mg} / \mathrm{Kg}$ but decreased when passing from first to second cycle of the different varieties. Gamma-tocopherol was the most abundant isomer.
\end{abstract}

Keywords: Palm Oil, Selection, Fatty Acids, Tocopherol

\section{Introduction}

Palm oil extracted from mesocarp of Elaies guineensis jacq is a food product frequently consumed in many parts of Africa, Asia and Eastern Europe. It is the most widely used vegetable oil in the world which serves as raw material for both food and non-food products [1]. In 2011 oil palm cultivation all over the world produced over 53 million metric tons of palm oil on 16 million hectares [2]. Currently, palm oil is the most produced vegetable oil in the world. The produced volume has increased from 15.2 million tons in 1995 to 54 million tons in 2011[3]. In Cameroon, palm oil meets $80 \%$ of total edible oil needs and it is estimated that $30 \%$ of crude palm oil production is provided by none industrial oil mills [4]

Besides various stages of selection, improvement of palm oil yield went through many steps. In 1960, a process of reciprocal recurrent selection of palm tree was introduced. Tenera, Dura and Pisifera varieties were included in this process. A cycle of selection proceeds by crossing seedlings from different origins and auto fecundation of hybrids [5]. This selection lays on the principle that oil yield and quality of fruits are controlled by many quantitative factors whose effects are additive. Hybrids obtained at the end of this process are more productive thanks to a good combination of factors [6]. Some improvement factors obtained from the sixties include reduction in height, appearance of disease tolerant strains and increase of oil yield [7]. As a matter of fact, oil yields shifted from $2 \mathrm{t} / \mathrm{ha}$ to $3.3 \mathrm{t} / \mathrm{ha}$ in the first cycle $[8,9]$. Second cycle material included best crossings with a yield $15 \%$ higher as compared to that of cycle one [10]. It appears necessary to investigate on possible chemical changes in oils resulting from different selection processes. Palm oil plays an important dietary role in Cameroon and many. It is therefore important to evaluate nutritional quality of oil produced by the three different varieties resulting from cycle one and cycle two reciprocal recurrent selections of palm trees in Cameroon. So, In this work, we determine and 
compare fatty acids and tocopherol contents of oil produced by Tenera, Dura and Pisifera varieties of Elaies guinensis jack from cycle one and cycle two reciprocal recurrent selections of this specie.

\section{Material and Methods}

\subsection{Oil Extracts}

Fruits from Tenera, Dura and Pisifera strains were used in these experiments. They belong to the first and second cycle of reciprocal recurrent selection and were harvested in an experimental farm of the National Research Centre on Palm Oil held by the Institute of Agronomic Research for Development (IRAD) of Dibamba (sea level, 47'60" North and $10^{\circ} 6^{\prime} 0 "$ East) (Republic of Cameroon). Fruits were brought down in dry weather at midday, vapour cooked for 35 minutes and pulped. Pulps were then crushed and oil extracted during 5 hours in hexane (Merck) using Soxhlet continuous extractor (at $65-71^{\circ} \mathrm{C}$ ). Solvent was eliminated by vacuum evaporation at $40^{\circ} \mathrm{C}$. After cooling in a desiccator, oil was transferred in small dark bottles and conserved away from light until analysis.

\subsection{Fatty Acids and Tocopherols Composition}

Analysis of methyl esters of fatty acids were carried out using a gaseous phase chromatograph AGILENT $6890 \mathrm{HP}$, equipped with a column SUPELCOWAX, $30 \mathrm{~m}$ length, 0.32 $\mathrm{mm}$ internal diameter and a film of $0.25 \mu \mathrm{m}$. Separations were performed in the following conditions: Helium was used as gas carrier with a flow rate of $1 \mathrm{~mL} / \mathrm{mn}$ at $250^{\circ} \mathrm{C}$. Flame ionization detector was at $270^{\circ} \mathrm{C}$. Flow rate was 35 $\mathrm{ml} / \mathrm{mn}$ and $350 \mathrm{ml} / \mathrm{mn}$ respectively for Hydrogen and air. Time required and the volume injected were respectively 20 $\mathrm{mn}$ injected and $1 \mu \mathrm{L}$. Temperature was programmed as follows: $185^{\circ} \mathrm{C}$ for $2 \mathrm{mn}$ followed by an increase from $4^{\circ} \mathrm{C} / \mathrm{mn}$ up to $225^{\circ} \mathrm{C}$ which remained until the end of required time $(20 \mathrm{mn})$. Identification of peaks was done on the basis of fatty acids profiles as well known in olive oil, palm oil and sunflower oil that were injected under the same operating conditions.

Tocopherols analysis was performed by HPLC in normal phase. The column used was Hypersil Si $60.5 \mu \mathrm{m} ; 4.6$ x 250 $\mathrm{mm}$ (Phenomenex, France). The solvent used under isocratic conditions was a mixture of hexane and isopropanol.

Statistical analysis: Each value is presented as mean \pm standard deviation for three replicates. Statistical analyses were carried out using Statistica version 6.0 sofware. Values were compared using Duncan test. Statistical significance was attained when a p-value was less than 0.05 .

\section{Results and Discussion}

Unsaturated Fatty Acids (UFA) contents found in first cycle palm oil were greater than $52 \%$ and there were no significant difference $(\mathrm{P}>0.05)$ between Tenera, and Pisifera varieties whatever be the selection cycle (Tables 1 and 2).
UFA contents of Dura palm oil decreased significantly from $52.82 \%$ to $47.45 \%$ when passing from first to second selection cycle. The ratio of polyunsaturated (PUFA) to saturated fatty acids (SFA) was almost twice higher in Pisifera (0.40) than in the two other varieties. Significant differences in fatty acids contents between first and second selection cycle were observed in Dura and Tenera palm oil. When passing from first to second reciprocal recurrent selection cycle. There was a significant increase in contents of myristic acid (C14: 0) palmitic acid (C16:0) and linoleic acid (C18: 2) for Dura variety. Stearic acid (C18:0) and oleic acid (C18: 1) contents decreased at the same time. However, the oleic acid, linolenic acid and arachidonic acid decrease significantly for Tenera variety (table 3). Palmitoleic acid (C16: 1) appears in both cycles of Pisifera and was no detected in Tenera and Dura first cycle palm oil.

Table 1. Fatty acids content of first cycle oil palm.

\begin{tabular}{llll}
\hline & \multicolumn{4}{l}{ First cycle oil palm varieties } \\
\hline Fatty acids (\%) & Tenera & Dura & Pisifera \\
\hline C14:0 & $0.42 \pm 0.65$ & $0.64 \pm 0.51$ & $0.51 \pm 0.01$ \\
C16:0 & $37.13 \pm 0.33$ & $39.74 \pm 1.38$ & $34.12 \pm 0.10$ \\
C16:1 & ND & ND & $0.10 \pm 0.01$ \\
C18:0 & $5.88 \pm 0.26$ & $6.24 \pm 0.20$ & $8.75 \pm 0.08$ \\
C18:1 & $45.10 \pm 0.50$ & $42.12 \pm 1.12$ & $37.76 \pm 0.09$ \\
C18:2 & $10.23 \pm 0.02$ & $10.13 \pm 0.17$ & $17.35 \pm 0.27$ \\
C18:3 & $0.33 \pm 0.03$ & $0.35 \pm 0.021$ & $0.39 \pm 0.04$ \\
C20:0 & $0.68 \pm 0.04$ & $0.56 \pm 0.07$ & $0.83 \pm 0.06$ \\
C20:1 & $0.21 \pm 0.03$ & $0.22 \pm 0.02$ & $0.19 \pm 0.02$ \\
UFA & 55.87 & 52.82 & 55.69 \\
PUFA/SFA & 0.24 & 0.22 & 0.40 \\
\hline
\end{tabular}

UFA: Unsaturated Fatty Acids

PUFA/SFA: Polyunsaturated fatty acid/ Saturated fatty acid ND: Non Detected

Table 2. Fatty acids content of second cycle oil palm.

\begin{tabular}{llll}
\hline \multicolumn{4}{l}{ Second cycle oil palm varieties } \\
\hline Fatty acids (\%) & Tenera & Dura & Pisifera \\
\hline C14:0 & $0.41 \pm 0.02$ & $1.23 \pm 0.03$ & $0.54 \pm 0.02$ \\
C16:0 & $37.74 \pm 0.30$ & $44.27 \pm 0.56$ & $34.41 \pm 0.07$ \\
C16:1 & $0.09 \pm 0.01$ & $0.10 \pm 0.01$ & $0.11 \pm 0.01$ \\
C18:0 & $6.43 \pm 0.08$ & $5.46 \pm .01$ & $8.84 \pm 0.06$ \\
C18:1 & $44.62 \pm 0.72$ & $35.91 \pm 1.22$ & $37.76 \pm 0.06$ \\
C18:2 & $9.83 \pm 0.19$ & $11.32 \pm 0.15$ & $17.08 \pm 0.05$ \\
C18:3 & $0.31 \pm 0.02$ & $0.36 \pm 0.01$ & $0.35 \pm 0.04$ \\
C20:0 & $0.58 \pm 0.01$ & $0.53 \pm 0.01$ & $0.76 \pm 0.02$ \\
C20:1 & $0.20 \pm 0.01$ & $0.16 \pm 0.02$ & $0.18 \pm 0.01$ \\
UFA & 55.05 & 47.85 & 55.48 \\
PUFA/SFA & 0.22 & 0.23 & 0.39 \\
\hline
\end{tabular}

UFA: Unsaturated Fatty Acids

PUFA/SFA: Polunsaturated fatty acid/ Saturated fatty acids

Pisifera total tocopherol contents were higher than Tenara's and Dura's. Individual tocopherol isomers $(\alpha, \beta, \gamma$ and $\delta$ ) content generally decreases from the first to the second reciprocal recurrent selection cycle (table 4).

Mean value of the analyzed crude palm oils was $53.79 \%$ and $46.21 \%$ respectively for unsaturated and saturated fatty acids. Other authors also found that oil palm is richer in UFA than in saturated fatty acids [11, 12]. According to FAO/WHO standards' unsaturated fraction of palm oil must 
be higher than $50 \%$ [13]. Polyunsaturated fatty acids contents is higher in Pisifera variety (more than 17\%) (Table 2). It can therefore been use as a potential source of these essentials nutrients. Polyunsaturated fatty acids are essential for many functions in the body: they can lower risk of heart desease, stroke and myocardial ischaemia. They also provide nutrients to help develop and maintain body cells. Oils rich in polyunsaturated fats also contribute vitamin $\mathrm{E}$ (a cell antioxidant vitamin) to the diet [14]. Increasing levels of saturated fatty acids was observed in Dura second cycle oil as a consequence of increase in palmitic acid content. Palmitoleic acid (C16: 1) was either absent or appeared in very small quantities only in the second cycle oil of Teneraand Dura. This low content may be due to a weak detection as was observed by Cochard and co-workers [9]. It has been shown that purified palmitoleic acid has lipidlowering and anti-inflammatory benefits in open label, epidemiologic, and animal studies [2]. Significant difference in fatty acids levels between first and second cycle indicated that strain selection in affects fatty acids profile of Dura and Tenera varieties. First cycle of reciprocal recurrent selection was launched on a rather broad genetic basis while second cycle selection used intrafamilial autofecundation based on a narrow genetic pool $[15,16]$. As a result, currently cultivated palm trees derived from a small gene pool [17]. Palm tree in industrial plantations of Cameroon are Dura/Pisifera hybrids coming from parents selected for their agronomic performance and characterized by the absence of consanguinity depression [18]. The rather long duration of a generation and type of pollinisation hamper genetic improvement of palm tree [19]. However, introduction of third cycle materials which implies evaluation of plants from 444 crossings [20] could reinforce genetic pool of oil palm. Total tocopherols levels display mean values similar to those of Nagendra and co-workers [12] but higher than those found in some wild oilseeds plants from Democratic Republic of Congo [21]. $\delta$-tocopherol stands for less than $26 \%$ of total tocopherols (table 4) which is lower than the value of $36 \%$ found in Malaysia palm oil [22]. Gamma-tocopherol appears as the major isomer with an average content of $364.5 \mathrm{mg} / \mathrm{Kg}$. Significant increase in tocopherol in second cycle oil would be due to increased synthesis from precursors such as squalene. It has been found that alpha-tocopherol mainly inhibits the production of new free radicals, while gammatocopherol traps and neutralizes the existing free radicals [23]. Thus, they might help to prevent or delay chronic diseases associated with reactive oxygen species molecules. This work shows that selection of oil palm tree resulted in some changes in chemical composition particularly in fatty acids and tocopherols.

Table 3. Comparison between first and second cycle's oil palm.

\begin{tabular}{|c|c|c|c|c|c|c|}
\hline & Tenera & & Dura & & Pisifera & \\
\hline Fattyacids (\%) & Cycle 1 & Cycle 2 & Cycle 1 & Cycle 2 & Cycle 1 & Cycle 2 \\
\hline $\mathrm{C} 14: 0$ & $0.42 \pm 0.65 \mathrm{a}$ & $0.41 \pm 0.02 \mathrm{a}$ & $0.64 \pm 0.51 b$ & $1.23 \pm 0.03 \mathrm{c}$ & $0.51 \pm 0.01 \mathrm{~d}$ & $0.54 \pm 0.02 \mathrm{~d}$ \\
\hline C16:0 & $37.13 \pm 0.33 a$ & $37.74 \pm 0.30 \mathrm{a}$ & $39.74 \pm 1.38 \mathrm{c}$ & $44.27 \pm 0.56 \mathrm{~d}$ & $34.12 \pm 0.10 \mathrm{e}$ & $34.41 \pm 0.07 \mathrm{e}$ \\
\hline C16:1 & ND & $0.09 \pm 0.01$ & ND & $0.10 \pm 0.01$ & $0.10 \pm 0.01 b$ & $0.11 \pm 0.01 \mathrm{~b}$ \\
\hline C18:0 & $5.88 \pm 0.26 \mathrm{a}$ & $6.43 \pm 0.08 b$ & $6.24 \pm 0.20 \mathrm{~b}$ & $5.46 \pm .01 \mathrm{a}$ & $8.75 \pm 0.08 c$ & $8.84 \pm 0.06 \mathrm{c}$ \\
\hline C18:1 & $45.10 \pm 0.50 \mathrm{a}$ & $44.62 \pm 0.72 b$ & $42.12 \pm 1.12 \mathrm{c}$ & $35.91 \pm 1.22 \mathrm{~d}$ & $37.76 \pm 0.09 \mathrm{e}$ & $37.76 \pm 0.06 \mathrm{e}$ \\
\hline C18:2 & $10.23 \pm 0.02 \mathrm{a}$ & $9.83 \pm 0.19 \mathrm{~b}$ & $10.13 \pm 0.17 \mathrm{a}$ & $11.32 \pm 0.15 \mathrm{c}$ & $17.35 \pm 0.27 \mathrm{~d}$ & $17.08 \pm 0.05 \mathrm{~d}$ \\
\hline C20:0 & $0.68 \pm 0.04 \mathrm{a}$ & $0.58 \pm 0.01 \mathrm{a}$ & $0.56 \pm 0.07 \mathrm{a}$ & $0.53 \pm 0.01 \mathrm{a}$ & $0.83 \pm 0.06 \mathrm{~b}$ & $0.76 \pm 0.02 b$ \\
\hline C20:1 & $0.21 \pm 0.03 \mathrm{a}$ & $0.20 \pm 0.01 \mathrm{a}$ & $0.22 \pm 0.02 \mathrm{a}$ & $0.16 \pm 0.02 \mathrm{a}$ & $0.19 \pm 0.02 \mathrm{a}$ & $0.18 \pm 0.01 \mathrm{a}$ \\
\hline UFA & 55.87 & 55.05 & 52.82 & 47.85 & 55.69 & 55.48 \\
\hline PUFA/SFA & 0.24 & 0.22 & 0.22 & 0.23 & 0.40 & 0.39 \\
\hline
\end{tabular}

Line values with the same letter are not significatively different at 5\% threshold.

UFA: Unsaturated Fatty Acids

PUFA/SFA: Polyinsaturated acids/Saturated fatty acids

ND: Non detected

Table 4. Tocopherol isomers content of oil palm varieties.

\begin{tabular}{|c|c|c|c|c|c|c|}
\hline & Tenera & & Dura & & Pisifera & \\
\hline Tocophérol (mg/Kg) & Cycle 1 & Cycle 2 & Cycle 1 & Cycle 2 & Cycle 1 & Cycle 2 \\
\hline & $211.33(1.53) \mathrm{a}$ & $202.00(2.00) \mathrm{b}$ & $185.33(1.53) \mathrm{c}$ & $110.33(1.53) \mathrm{d}$ & $195.67(3.05) \mathrm{e}$ & $181.34(1.53) \mathrm{f}$ \\
\hline & $287.33(2.52) \mathrm{a}$ & $240.34(2.52) b$ & $320.33(1.15) \mathrm{c}$ & $206.35(1.53) \mathrm{d}$ & $327.34(1.53) \mathrm{e}$ & $315.67(1.15) \mathrm{f}$ \\
\hline & $355.66(2.08) \mathrm{a}$ & $340.67(0.58 b$ & $345.00(3.00) \mathrm{c}$ & $333.67(1.15) d$ & $414.67(1.15) \mathrm{e}$ & $402.67(1.53) f$ \\
\hline & $30.33(1.53) \mathrm{a}$ & $18.00(1.00) b$ & $39.67(1.53) \mathrm{c}$ & $87.66(0.58) \mathrm{d}$ & $116.34(1.53) \mathrm{e}$ & $98.34(0.57) \mathrm{f}$ \\
\hline Totals & 884.65 & 801.01 & 890.33 & 738.01 & 1054.02 & 998.02 \\
\hline
\end{tabular}

Line values with the same letter are not significantly different at $5 \%$ threshold.

Values in brackets are \pm standard deviations

\section{Conclusion}

The three varieties of Elaeis guinensis generally have high contents of unsatured fatty acids and gamma tocopherol which do not varie significatively according to selection cycle. Genetic selection so far applied on palm tree which has passed through two cycles of reciprocal recurrent selection has not significantly altered fatty acids balance but 
led to some significant changes in fatty acids and tocopherols profiles of oil palm.

\section{Acknowledgements}

The authors wish to thank the Institute of Agricultural Research for Development (IRAD) in Dibamba- Cameroon for having provided samples for the whole study.

\section{References}

[1] Fournier, S., Peter, A., Claude, J., La transformation artisanale de l'huile de palme au Bénin et Nigeria. 34398, Montpellier Cedex 5, France. 139p (2001).

[2] Roizen M. F., Martinez L. Purified palmitoleic acid for the reduction of high-sensitivity C-reactive protein and serum lipids: A double-blinded, randomized, placebo controlled study. Journal of clinical lipidology. 8(6): 612-617 (2014).

[3] Levin J., WWF-US. Profitability and Sustainability in Palm Oil Production. Analysis of Incremental Financial Costs and Benefits of RSPO Compliance. Report of WWF. 49p (2012).

[4] Ngando Ebongue G. F., Mpondo Mpondo E. A., Dikotto Ekwe E. L., Koona P. Assessment of the quality of crude palm oil from smallholders in Cameroon. Journal of Stored Products and Postharvest Research 2(3) 52-58( 2011).

[5] Benard, Malingraux. La production de semences sélectionnées de palmier à huile à l'IRHO. Principe et réalisation. Oléagineux, 36: 297-302 (1965).

[6] Adon B., Cochard B., Flori A., Potier F., Quencez D. G. T. Introgression de la croissance lente dans les populations améliorées de palmier à huile (E. guinensis jacq.). Forum Internatinal congress, Kuala Lumpur, Malaysia, 22-26 (2001).

[7] Cochard B., Adon B., Kouame K. R., Durand-Gasselin T. Intérêt des semences commerciales améliorées de palmier à huile (Elaeis guineensis Jacq.). Oléagineux, Corps Gras, Lipides. 8(6): 654-658. (2001).

[8] Flood J., Mepsted R. Comparison of virulence of isolated of fusarium oxysporumf.sp. elaeidis from Africa and South America. Plant Pathol. 42: 168-171 (1993).

[9] Cochard, B., Amblard P., Durand-Gasselin T. Oil palm genetic improvement and sustainable development. Oléagineux, Corps gras, Lipides. 12(02): 141-147 (2005).

[10] Kritchevsky D., Tepper S. A., Czarnecki S. K., Sundram K. Red palm oil in experimental atherosclerosis. 2001 PIPOC international palm oil congress. Food technology and nutrition conference. 20-22 August 2001. 87-94 (2001).
[11] Rukmini, C. 1994. Red palm oil to combat vitamin A deficiency in developing countries. Food and Nutrition Bulletin. 15 (2): 126-129.

[12] Nagendra B., Unitrans U. R., Choo Y. M., Sundran K. Characteristic of red palm oil, a carotene- and vitamin E-rich refined oil for food uses. Food and Nutrition Bulletin.124: 189-194 (2000).

[13] FAO/WHO. Programme mis sur les normes alimentaires: commission du codex alimentarius. Graisse et Huile. Rome (Italie). 62p (1993).

[14] Karsten H., Weylandt, S. S., Yong Q. C., Hui-Min S., Kyu L., Cittadini A., Calviello G. Omega-3 Polyunsaturated Fatty Acids: The Way Forward in Times of Mixed Evidence. BioMed Research International. 2015. 24p. (2015).

[15] Ravigadevi S. Kalyana S., Yem-Aitan Yew-Ai, T. Chemistry and biochemistry of palm oil. Progress in Lipid Research39: 507-558 (2000).

[16] Gallais A., Amélioration des populations, méthodes de sélection et création de variétés. Ann. Amél. Plantes, 27:( 3). 281-330 (1977).

[17] Durand-Gasselin, T., Kouame, K. R., Cochard B., Adon, B., Amblard P. Diffusion variétale du palmier à huile (Elaeis guineensis jacq). Oléagineux, Corps Gras, Lipides. 7: 207-214 (2000).

[18] Durand-Gasselin T., Baudouin C., B., Adon B., Cao T. V. Stratégies d'amélioration génétiques du palmier à huile. Plantation Recherche Développement. 6: 344-353 (1999).

[19] CNRA (Centre National de la Recherche Agronomique). Les programmes de recherche 2012-2015. Côte d'Ivoire. CNRA. p19. (2012)

[20] Lago R. C. A., Hartman L. Directed interesterification of a brazilian palm oil and analysis of the original and interesterified oil and its fractions. J. Sci. Food Agric. 37: 689693 (1986).

[21] Kazadi M., Kadima J. N., Kaaya A. N., Matthäus B. Van Damme P., Bashwira S., Mosibono D. E., Katula B., Mpiana P. Fatty acids and tocopherols content in fractionated oils from five wild oilseed plants Native to Kahuzi-Biega National Park, Kivu-DR Congo. European Journal of Medicinal Plant. 10(1): 1-9 (2015).

[22] Choo N. M., Maan Y. M., Chuah, C., Hashim M. Separation of vitamin $\mathrm{E}$ (tocopherol, tocotrienol, and tocomonoenol) in palm oil. Lipids. 39(10): 1031-1035 (2004).

[23] Saliha R., Syed T. R., Faizal A., Absar A., Shania A., Farzana M.. The role of Vitamin $\mathrm{E}$ in human health and some diseases. Sultan Qaboos Univ Med J. 14(2): 157-165 (2014). 